\title{
UPPER CRETACEOUS (MAASTRICHTIAN) LANDVERTEBRATE DIVERSITY IN ALBA DISTRICT (ROMANIA)
}

\author{
Codrea V. ${ }^{1}$, Barbu O. ${ }^{1}$ and Jipa-Murzea C. ${ }^{2}$ \\ ${ }^{1}$ Babeş-Bolyai University, Faculty of Biology-Geology, Department of Geology-Paleontology, \\ 1 Kogălniceanu Str., 400084 Cluj-Napoca, Romania; corresponding author:vlad.codrea@ubbcluj.ro \\ ${ }^{2}$ Babeş-Bolyai University, Faculty of Environment Science, 30 Fântânele Str., \\ 400294, Cluj-Napoca, Romania
}

\begin{abstract}
In Romania, Maastrichtian (Late Cretaceous) dwarf dinosaur remains were first reported from the Hatseg basin by the Baron Franz Nopcsa, at the end of $19^{\text {th }}$ century. Later, the same expanded his research to others areas of Transylvania, adding new localities with comparable Maastrichtian vertebrate assemblages in Alba and Sălaj Counties. Following Nopcsa, both these regions and topics have not been studied for a long time. In the last decade, new field works succeeded in finding rich and diverse Maastrichtian terrestrial vertebrate fauna in Alba County restricted to a distinct Late Cretaceous sedimentary area (Metaliferi). For these studies, the Sard Formation is of main interest. In this formation, the Maastrichtian is developed in fluvial system environments which are documented by flood plain overbank and channel fill deposits. Besides fishes, amphibians, birds and mammals, the fossils embrace mainly various dinosaurs such as sauropods, hadrosaurs, ornithopods, ankylosaurs, various small-sized theropods, as well as other reptiles as turtles and crocodilians. Often, the remains are fragmentary and dislocated. Besides the Haţeg basin, the Metaliferi area is the second important region documenting the Maastrichtian terrestrial biota in Romania.
\end{abstract}

Key words: Romania, Transylvania, Late Cretaceous, dinosaurs, land vertebrates.

\section{Introduction}

Maastrichtian dinosaur localities are scarce in Europe (northern Spain, southern France, and Romania). In Romania, the first Maastrichtian dwarf dinosaurs had been reported since over a century ago by Baron Franz Nopcsa, in the Haţeg basin. The same continued his survey also to other areas from Transylvania as in Alba and Sălaj counties where he found comparable Maastrichtian vertebrates (Nopcsa, 1905). Later, other studies underlined the remarkable abundance (Grigorescu, 1992; Grigorescu et al., 1999) and diversity of these assemblages (Codrea et al., 2002a; Smith et al., 2002).

Nopcsa assumed the presence of Maastrichtian deposits rather southwestern Transylvania at Vurpăr and Lancrăm (Nopcsa, 1905; 1909), where he found mainly ornithopod remains. Except few contributions (e.g. Grigorescu, 1987) pointing out mainly the low potential of Alba Maastrichtian localities, the area has hardly been studied for several decades after Nopcsa. In '90, new works carried out in Alba County by palaeontologists of "Babeş-Bolyai University”, succeeded in adding new localities with Maastrichtian terrestrial vertebrates to those already known before (Codrea et al., 2001, 2002b, 2009). These finds enlarged the knowledge on this biota considerably by recording new taxa 


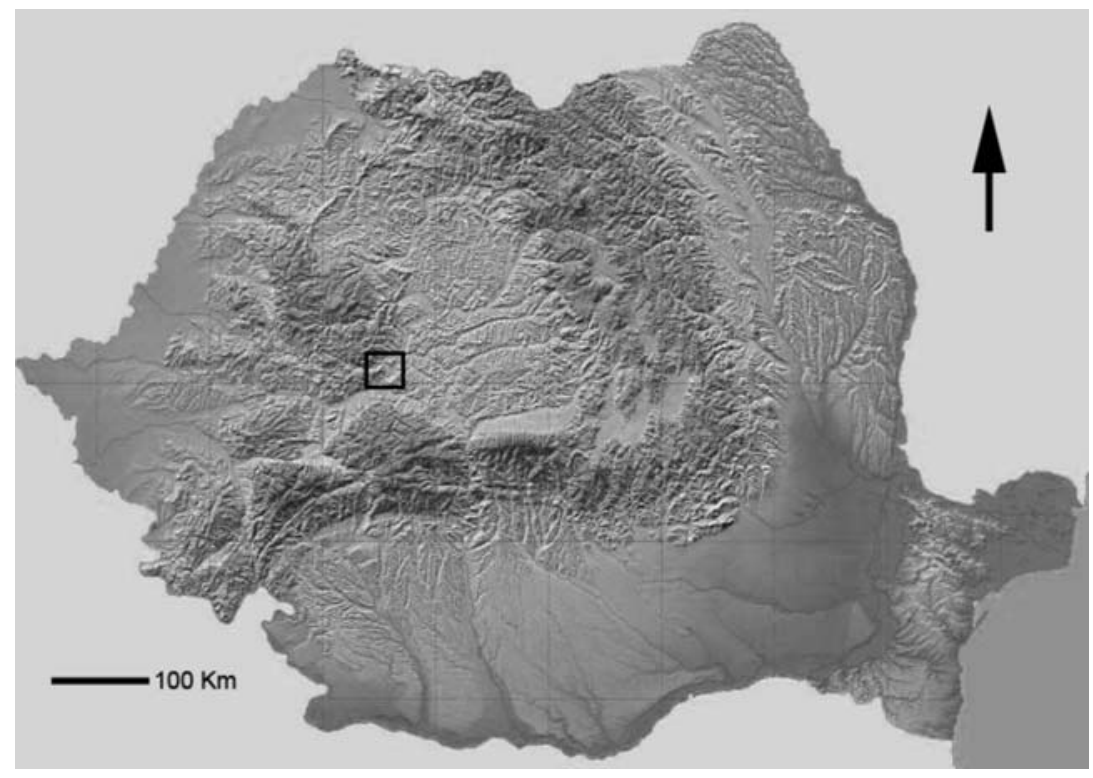

Fig. 1: Location of the Maastrichtian Metaliferi sedimentary area in Romania.

for this region. Codrea and Dica (2005) outlined a distinct sedimentary area in Alba County with Late Cretaceous formations named Metaliferi area (Fig. 1). The Alba continental formations are probably coeval with the Sânpetru Formation of the Haţeg basin. The paleomagnetic studies evidenced that the Sânpetru Formation is Lower Maastrichtian (Panaiotu \& Panaiotu, 2002, 2009). However, palynological data (Antonescu, 1973; Antonescu et al., 1983) indicate that the samples collected in the Pâclişa Valley (south Alba Iulia) would be Late Maastrichtian age, according to the Pseudopapillopollis praesubhercynicus Goczan, Groot, Krutzch, Pacltova, 1967 assemblage. Obviously, more data are needed for a refined stratigraphy of the area.

\section{Geological setting}

Located in southwestern Transylvania, in the Metaliferi sedimentary area Upper Cretaceous-Lower Miocene formations (Codrea et al., 2003; Codrea \& Dica, 2005) marine and continental environments are inerbeded.

A Maastrichtian continental sequence can be observed between the Bozeş and Ighiu formations. It begins with the Vurpăr Formation (deltaic sequence, interrupted by several short marine ingressions) and Şard Formation (fluvial red beds, with flood plain red silty clay and conglomerate and arenitic channel fills (Codrea et al., 2001, 2009). Mainly the last bears relatively numerous vertebrate fossils. In both formations, the bases and tops are obvious well-defined due to the turnover of environments which are reflected in their lithologies. The first one is dominated by yellowish sand and sandstones, the second by red beds.

While the base of the Şard Formation is doubtless Maastrichtian, the age of the top is less clear: the sedimentation may have lasted into the Paleogene but currently there is no evidence. It may therefore also be presumed that the whole sequence could be exclusively of Maastrichtian age. Its clastic input probably originated from two source areas: one at the Apuseni Mountains, and a second at the South Carpathi- 
ans. The detrital inputs from these two sources interfered toward the centre of the sedimentary basin.

The first type of lithoclasts originates from magmatic acid and basic rocks, Upper Jurassic limestones, jaspers, Cretaceous sandstones, metamorphic rocks, which are reworked in conglomerates and arenites. It can be observed in a series of red beds outcrops between Vurpăr-Pâclişa-Şard-Bărăbanţ, deposited over the folded nappes of the Apuseni Transylvanids (Săndulescu, 1984). In the Vurpăr and Stăuinii Valley, the vertebrate fossils occur mainly in the basal part of this succession, but are extremely scarce toward its top. The entire sequence suggests a braided fluvial system with channels fills of sand and gravel, internal bars and overbank accumulations with red silt and pedogenetic levels. Here and there, as at Oarda de Jos, the fluvial system developed pond-like deposits with tendencies of forming small lakes in part represented by grey-blackish silt clay (Codrea et al., 2001).

The second source area discharged mainly metamorphic and pegmatitic clasts, filling numerous channels. Such red beds are exposed at Petreşti, Râpa Roşie and Râpa Lancrămului (near Sebeş and Lancrăm). While the first locality was only found recently, the other exposures are notorious in Romania, being geological areas under protection (Toniuc et al., 1992). However, the geological age of these red beds is rather controversial. Until now, there was a general consensus for a Cenozoic age (e.g. Grigorescu, 1987, Codrea \& Dica, 2005 etc). The evidence was the existence of nummulite limestone pebbles and boulders inside these deposits. In fact, these Paleogene limestones -which can be found in Râpa Roşie-, originate from reworked rocks of the transgressing marine Middle Miocene (Badenian) that overlies the red beds. They are simply rolling down the scarp and remain trapped in the red mud after heavy rainfalls. Therefore, the nummulite limestone does not belong to this formation. The fossils reported from these deposits are exclusively those of Late Cretaceous reptiles (Koch, 1894, 1900; Grigorescu, 1987; Jianu et al., 1997; Codrea \& Vremir, 1997; Codrea et al., 2008), being apparently reworked: the bones are white and broken the tips eroded, indicating transportation. However, these features are only valid for the fossils collected from the basal sequence of the red beds in Râpa Roşie but not in its upper part. In fact, the upward fining tendency in this locality has already been before (Grigorescu et al. 1990), but this sedimentary trend remained devoid of explanation. Recently, a cervical vertebra of a huge azhdarchid pterosaur was found in the upper portion of the Râpa Roşie red beds sequence (Vremir et al., 2009). The bone does not show any marks of reworking. Anyhow, such a fragile bone could never be ever reworked without breaking into pieces. Besides this vertebra, other reptile bones found in the same section are devoid of reworking marks, too. Considering this, the red beds from Râpa Roşie should be reassessed to the Maastrichtian, Şard Formation, too.

\section{The Maastrichtian biodiversity}

In all outcrops the vertebrate remains are not very rich. The bones of the large size reptiles are frequently broken and the fragments scattered. However, occasionally, parts of skeletons in anatomical connection occur, as in Vurpăr (Codrea et al., 2009) or Sebeş-Glod, thus documenting the autochthonous status of the fossils. The majority of the red beds outcrops (Vurpăr, Stăuinii Valley, Râpa Roşie, Râpa Lancrămului, Petreşti) yielded white or coloured bones with cracks on their surfaces, proving long weathering before burial. On the opposite, in localities (Oarda de Jos; Codrea et al., 2001, 2009) with pond sedimentation, the fossilisation is completely different, with black or grey coloured bones. In these environments, the bones frequently originated from the preys of crocodile (frequent bite-marks on numerous crocodile bones; Delfino et al., 2008). The burial of the bones into the mud was faster there.

The macrovertebrate remains were collected by annual monitoring of the localities over a decade. The survey has led to a rich collection of various teeth and bones, originating from different vertebrate taxa. 
The majority belongs to reptiles, but other groups are well represented too. The fossils are housed in the "Babeş-Bolyai” University Cluj-Napoca, Department of Geology - Palaeontology. Besides macrovertebrates, microvertebrates are also present in the Maastrichtian fossil record for the Metaliferi area.

\section{Reptiles}

\section{Dinosaurs}

The dinosaur teeth and bones are sometimes fairly well preserved. The faunal assemblage includes titanosaurids, a hadrosaur, ornithopods, an ankylosaur, and theropods.

The sauropod titanosaurs are well documented at Sebeş, Oarda de Jos and Lancrăm, but are missing in other places, as Vurpăr. Samples include femora, humeri, tibia, fibulae and mostly caudal vertebrae. The skulls are unknown, probably due to taphonomic reasons. The limb bones are usually well preserved, as the tibia illustrated in Fig. $2 \mathrm{a}$.

The single notorious basal hadrosaur known from Romania, Telmatosaurus transsylvanicus is attested by one scapula, several tibiae (more or less well preserved) and femora. The most important outcrops where it is well represented are Lancrăm, where 7 pieces have been found and Oarda de Jos, with 2 pieces only.

Besides the hadrosaur, the other ornithopod dinosaurs belong to Zalmoxes. These fossils are very frequent in Vurpăr. The samples include cranial and limb bones as fibulae, humeri, tibiae, as well as numerous dorsal and caudal vertebrae. Some fair preserved isolated teeth have been collected in Vurpăr (Fig. 2d).

The nodosaurid ankylosaur (the only genus reported from the Maastrichtian in Romania is Strutiosaurus) is documented by a large number of dorsal and caudal vertebrae, fragments of femora and numerous osteoderms (Fig. 2b).

Remains of Theropod dinosaurs are scarce. They consist only of isolated teeth which seem to evidence a rather large diversity, assigned to Velociraptorinae or Theropoda incertae sedis (Fig. 2g).

The dinosaur teeth and bones are sometimes accompanied by eggshell fragments. These fragments are extremely numerous in Oarda de Jos and are referring to four types (Monique Vianey-Liaud, Montpellier, written communication 2008) including ?Pseudogeckoolithus and Megaloolithidae, pointing to similarities with the eggshells reported from the Haţeg basin (Grigorescu et al., 1990, 1994; Codrea et al., 2002a; Smith et al., 2002; Csiki et al., 2008).

\section{Crocodilians}

Crocodilian remains are numerous in Oarda de Jos, being represented by many isolated teeth and skull fragments. The best-preserved and most complete skull ever discovered originates from Oarda. It belongs to the eusuchian Allodaposuchus precedens (Delfino et al., 2008). The isolated teeth are either highly conical, with small smooth mesial and distal carinae, belonging to Allodaposuchus precedens (Fig. 2c) or short, broad triangular and labio-lingually compressed, probably belonging to Doratodon.

\section{Turtles}

There are several fragments from plastron and carapaces, vertebrae and leg bones, the majority originating from Oarda. Most of the material collected belongs to a Dortokid species (Vremir \& Codrea, 2009; Lapparent et al., 2009). The remains of the species Kallokibotion bajazidi are less abundant (Codrea \& Vremir, 1997; Vremir, 2004; Vremir \& Codrea, 2009; Lapparent et al., 2009). 


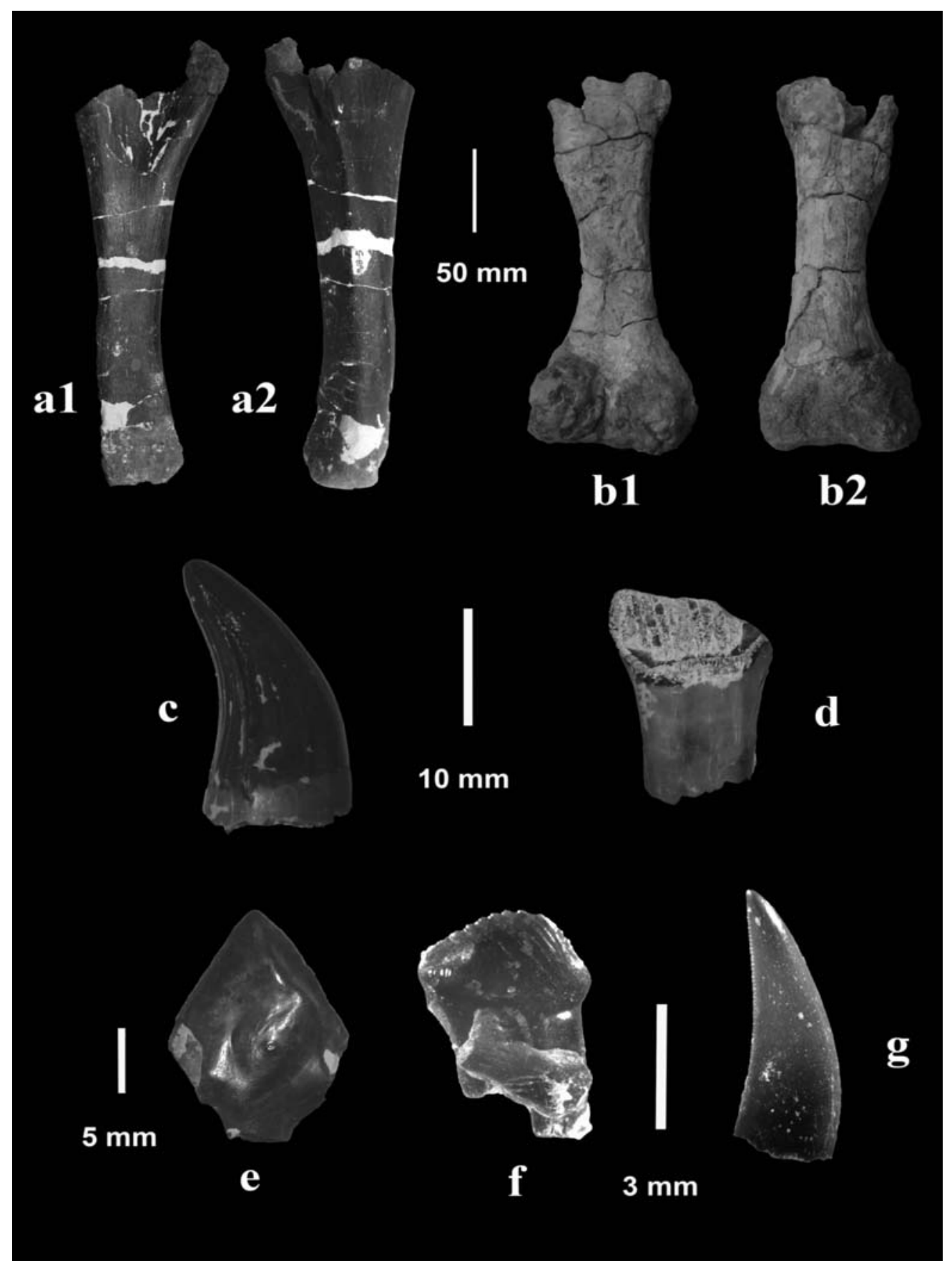

Fig. 2: Maastrichtian vertebrates from Alba County: (a1, a2) Titanosauria, right tibia (UBB OdB-5), posterior and anterior views; (b1, b2) Struthiosaurus transilvanicus, right femur (UBB VP-26), posterior and anterior views; (c) Allodaposuchus precedens, tooth; (d) Zalmoxes sp., isolated tooth (UBB VP-71), lingual view; (e) Lepisosteidae fish scale, Oarda de Jos, external view; (f) Multituberculate tooth: Kogaionidae indet., p4, lateral view; (g) Theropoda incertae sedis, tooth, lateral view. 


\section{Other vertebrates}

\section{Fish}

The sample includes around 100 teeth, many vertebrae and scales (Fig. 2e). According to teeth and scale morphologies they mainly belong to the Lepisosteidae.

\section{Amphibians}

Numerous maxillary fragments with various numbers of teeth are preserved, distal ends of humeri, ulnae, frontals and vertebrae: axis, atlas and sacral refer to the Albanerpetontidae (Allocaudata). Frog remains include limb elements such as urostylae, fused tibiofibulae and radi-ulnae.

\section{Lizards}

Fossils such as jaws and dentitions prove the presence of several lizard species. One of them exposes slightly tricuspid and cylindrical teeth. A well-preserved frontal belongs to the same group.

\section{Mammals}

Like in the Haţeg basin, the only mammal remains collected from this area are those of Kogaionidae multituberculates (more than 30 isolated upper and lower teeth document this group; Fig. 2f). They were collected by screen-washing about 1.8 ton of sediments. The Eutherians remain unknown from this biota.

\section{Conclusions}

The dinosaur assemblage of the Metaliferi area is similar with to the notorious ones reported from different localities of the Haţeg Basin. Outlining an inland area, the dinosaurs from Alba County supplement the knowledge of the environments and the paleogeography of the Late Cretaceous in Transylvania, where these taxa evolved from (Nopcsa, 1914; Codrea et al., 2009). Preliminary studies on microvertebrates add new data about the Maastrichtian terrestrial ecosystem, increasing the systematic biodiversity. They may yield additional details for reconstructing the Maastrichtian climates and biota in Transylvania.

\section{Acknowledgments}

This research work for Cătălin Jipa-Murzea was financed from the POS DRU project 6/1.5/S/3 "Doctoral studies through science towards society". Vlad Codrea was partially supported by the CNCSIS grant 1930/2009. We thank to all participants of the field missions: their number is too large for mentioning all names. Last but not least, we thank the anonymous reviewers for improving this text.

\section{References}

Antonescu, E., 1973. Asociaţii palinologice caracteristice unor formaţiuni cretacice din Munţii Metaliferi. Dări de Seamă ale şedinţelor Institutului de Geologie şi Geofizică al României, LIV, p.115-149, Bucureşti.

Antonescu, E., Lupu, D., Lupu, M., 1983. Corrélation palynologique du Crétacé terminal du sud-est des Monts Metaliferi et des Dépressions de Haţeg et de Rusca Montană. Anuarul Institutului de Geologie şi Geofizică, Stratigrafie, 59, p.71-77, Bucureşti.

Codrea, V., Vremir, M., 1997. Kallokibotion bajazidi Nopcsa (Testudines, Kallokibotidae) in the red strata 
of Râpa Roşie (Alba County). Sargetia, 17, p.233 - 238, Deva.

Codrea, V., Hosu Al., Filipescu S., Vremir, M., Dica, P., Săsăran, E., Tanţău, I., 2001. Aspecte ale sedimentaţiei cretacic superioare din aria Alba-Iulia. Studii şi cercetări (Geologie-Geografie), 6, p. 6368, Bistriţa.

Codrea, V., Smith, T., Dica, P., Folie, A., Garcia, G., Godefroit, P. \& Van Itterbeeck, J., 2002a. Dinosaur egg nests, mammals and other vertebrates from a new Maastrichtian site of the Haţeg Basin (Romania). Compte Revue Palevol, 1, 3, p.173-180, Paris.

Codrea, V., Săsăran, E., Dica, P., 2002b. Vurpăr (Vinţu de Jos, Alba district). In: The 7th European Workshop of Vertebrate Palaeontology, Abstract Volume and Excursions Field Guide, p. 60-62, Sibiu.

Codrea, V., Dica, P., Fărcaş, C., Barbu, O., 2003. Late Cretaceous-Early Miocene formations from Alba Iulia - Sebeş area (Transylvanian Depression, Alba district). Oltenia, Studii şi comunicări, Ştiinţele naturii 19 , p. 22-27, Craiova.

Codrea, V., Dica, P., 2005. Upper Cretaceous-lowermost Miocene lithostratigraphic units exposed in Alba Iulia - Sebeş - Vinţu de Jos area (SW Transylvanian basin). Studia Universitatis Babeş-Bolyaii, Geologia, 50, (1-2), p. 19-26, Cluj-Napoca.

Codrea, V., Murzea-Jipa, C., Venczel, M., 2008. A sauropod vertebra at Râpa Roşie (Alba district). Acta Palaeontologica Romaniae, 6, p. 43-48, Iaşi.

Codrea, V., Vremir, M., Jipa, C., Godefroit, P., Csiki, Z., Smith, T., Fărcaş, C., 2009. More than just Nopcsa's Transylvanian dinosaurs: A look outside the Haţeg Basin. Palaeogeography, Palaeoclimatology, Palaeoecology, doi: 10.1016/ j.palaeo.2009.10.027

Csiki, Z., Ionescu, A., Grigorescu, D., 2008. The Budurone microvertebrate fossil site from the Maastrichtian of the Haţeg Basin - flora, fauna, taphonomy and paleoenvironment. Acta Palaeontologica Romaniae, 6, p. 49-66, Iaşi.

Delfino, M., Codrea, V., Folie, A., Dica, P., Godefroit, P., Smith, T., 2008. A complete skull of Allodaposuchus precedens NOPCSA, 1928 (Eusuchia) and a reassessement of the morphology of the taxon based on the Romanian remains. Journal of Vertebrate Paleontology, 28, p.111-122.

Grigorescu, D., 1987. Considerations on the age of the «red beds» continental formations in south-western Transylvanian Depression. In: The Eocene from the Transylvanian Basin (I. Petrescu, L. Ghergari, N. Mészáros, E. Nicorici Eds), Universitatea “Babeş-Bolyai” Cluj, p.189-196, Cluj-Napoca.

Grigorescu, D., 1992. Nonmarine Cretaceous formations of Romania. In: Mateer, N., Pen-Ji, C. (Eds.), Aspects of Nonmarine Cretaceous Geology, Special vol., ICGP Project 245, China Ocean Press, p. 142-164.

Grigorescu, D., Şeclăman, M., Norman, B.D., Weishampel, D.B., 1990. Dinosaur eggs from Romania. Nature, 346, p. 417.

Grigorescu, D., Avram, E., Pop, G., Lupu, M., Anastasiu, N., Rădan, S., 1990. 5. Description of itineraries and outcrops. Excursion A. In: D. Grigorescu, E. Avram, G. Pop, M. Lupu, N. Anastasiu \& S. Radan (eds.), International geological correlation program (project 245: Nonmarine Cretaceous correlation; project 262: Tethyan Cretaceous correlation): Guide to excursions. Institute of Geology and Geophysics: p. 73-93, Bucharest.

Grigorescu, D., Weishampel, D.B., Norman, D.B., Şeclăman, M., Rusu, M., Baltreş, A., Teodorescu, V., 1994. Late Maastrichtian dinosaur eggs from the Hateg Basin (Romania). In: Carpenter, K., Hirsch, K.F., Horner, J.R. (Eds.), Dinosaur Eggs and Babies. Cambridge University Press, p. 75-87.

Grigorescu, D., Venczel, M., Csiki, Z., Limberea, R., 1999. New latest Cretaceous microvertebrate fossil assemblages from the Haţeg Basin (Roumania). Geologie en Mijnbouw, 78, p. 301- 314, Dordrecht.

Jianu, C., M., Mészàros, N., Codrea, V., 1997. A new collection of Haţeg and Râpa Roşie material (Di- 
nosauria, Crocodilia, Chelonia) in the Cluj-Napoca University. Sargetia, XVII, p. 219-232, Deva.

Koch, A., 1984. Die Tertiärbildung des Beckens der Siebenbürgischen Landestheile.I.Paläogene Abtheilung. Mitteilung aus dem Jahrbuch der Kön. Ungarische Geologischen Anstalt, X, 6, p.177-399, Budapest.

Koch, A., 1900. Az Erdélyrészi medencze harmadkori képződményei. II. Neogen csoport. Fóldtani Intezet Évkonyve, p. 329, Budapest.

Lapparent, F., Codrea, V.A., Smith, T., Godefroit, P., 2009. New turtle remains (Kallokibotionidae, Dortokidae) from the Upper Cretaceous of Transylvania (Romania). The $7^{\text {th }}$ Romanian Symposium of Paleontology, Abstract book, p. 68-69, Cluj-Napoca.

Nopcsa, F., 1905. A Gyulafehérvár, Déva, Ruszkabánya és a Romániai határ közé eső vidék geológiája. A magyar Királyi Földtani Intézet Évkönyve 14, p. 82-254, Budapest.

Nopcsa, F., 1914. Über das Vorkommen der Dinosaurier in Siebenbürgen. Verhandlungen der Zoologischen und Botanischen gessellschaft 54, p. 12-14.

Panaiotu, C., Panaiotu, C., 2002. Paleomagnetic studies. In 7th European Workshop on Vertebrate Paleontology, Abstracts volume and excursions field guide, p. 61, Sibiu.

Panaiotu, C., G., Panaiotu, C. E., 2009. Palaeomagnetism of the Upper Cretaceous Sânpetru Formation (Haţeg Basin, South Carpathians), Palaeogeography, Palaeoclimatology, Palaeoecology, doi: 10.1016/j.palaeo.2009.11.017

Săndulescu, M., 1984. Geotectonica României. Ed. Tehnică, p. 336, Bucureşti.

Smith, T., Codrea, V., Săsăran, E., Van Itterbeeck, J., Bultynck, P., Csiki, Z., Dica, P., Fărcaş, C., Folie, A., Garcia, G., Godefroit, P., 2002. A new exceptional vertebrate site from the Late Cretaceous of the Hateg Basin (Romania). Studia Universitatis Babes-Bolyai, Geologia, Special issue 1, p. 321-330, Cluj-Napoca.

Therrien, F., Jianu, C.-M., Bogdan, S., Weishampel, D.B., King, J.W., 2002 . Paleoenvironmental reconstruction of the Latest Cretaceous dinosaur-bearing formations of Romania: preliminary results. Sargetia, Scienties Naturalis, 19, p. 33-59, Deva.

Therrien, F., 2005. Paleoenvironments of the Late Cretaceous (Maastrichtian) dinosaurs of Romania: insights from fluvial deposits and paleosols of the Transylvanian and Haţeg basins. Palaeogeography, Palaeoclimatology, Palaeoecology, 218, 1-2, p. 15-56.

Toniuc, N., Oltean, M., Romanca, G., Zamfir, M., 1992. List of protected areas in Romania (1932-1991). Ocrotirea naturii şi a mediuluiînconjurător, 36, 1, p. 23-33, Bucureşti.

Vremir, M., 2004. Fossil Turtle found in Romania - overview. A Magyar Földtani Intézet Évi Jelentèse, 2002, p. 143-152, Budapest.

Vremir, M., M., Codrea, V., A., 2009. Late Cretaceous turtle diversity in Transylvanian and Haţeg basins (Romania). The $7^{\text {th }}$ Romanian Symposium of Paleontology, Abstract book, p. 122-124, Cluj-Napoca.

Vremir, M., M., Unwin, D., M., Codrea, V., A., 2009. A giant Azhdarchid (Reptilia, Pterosauria) and other Upper Cretaceous reptiles from Râpa Roşie-Sebeş (Transylvanian basin, Romania) with reassessment of the age of the "Sebeş Formation". The $7^{\text {th }}$ Romanian Symposium of Paleontology, Abstract book, p. 125-128, Cluj-Napoca.

Weishampel, D., B., Jianu, C.-M., Csiki, Z., Norman, B., D., 2003. Osteology and phylogeny of Zalmoxes (n.g.), an unusual Euornithopod dinosaur from the Latest Cretaceous of Romania. Journal of Systematic Palaeontology, 1 (2), p. 65-123, London. 